УДК 341.645.5

DOI https://doi.org/10.32849/2663-5313/2020.4.64

\title{
Анастасія Здебська,
}

студентка факультету адвокатури

Начіонального юридичного університету імені Ярослава Мудрого

\section{Інна Мороз,}

студентка господарсько-правового факультету

Національного юридичного університету імені Ярослава Мудрого

\section{ВИКОНАННЯ РІШЕНЬ ЄВРОПЕЙСЬКОГО СУДУ 3 ПРАВ ЛЮДИНИ В УКРАЇНІ}

Стаття присвячена дослідженню питань щодо порядку введення в дію рішень Свропейського суду з прав людини, який є контрольним механізмом Конвенції про захист прав людини і основоположних свобод та головним призначенням якого є нагляд за дотриманням прав, закріплених у Конвениії. Зазначається обов'язковий характер таких рішень, оскільки відповідно до чинного законодавства начіональні суди, розглядаючи справи, застосовують Конвениію та практику Європейського суду з прав людини як джерело права.

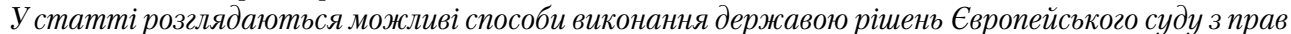
людини, різні підходи науковців щодо иього та визначається специфіка виконавчого провадження, яка зумовлена особливим статусом органу, який приймає такі рішення. Визначається роль Парламентської Асамблеї Ради Свропи та Комітету Міністрів Ради Свропи у механізмі виконання рішень Європейського суду з прав людини.

Увага акиентується на наявній проблемі щодо не дуже високих показників та тривалості виконання рішень Європейського суду з прав людини, внаслідок чого констатується порушення Украйною Конвениії; аналізуються чинники, які зумовили таке становище. Надається статистика рівня виконання рішень за 2015-2019 роки. Розглядається відповідальність держави перед особою, щодо якої було постановлено рішення, за несвоєчасне його виконання.

Висвітлюються системні проблеми, наявність яких в Украӥні є перешкодою для належного виконання рішень Європейського суду з прав людини.

Наголошується на тому, що виконання судових рішень постає доказом того, що в нашій державі дійсно є гарантії забезпечення права людини на справедливий судовий розгляд, однак низький рівень такого виконання змушує розглядати такі гарантії як декларативні. У статті перелічуються захо$\partial u$, яких вживає наша держава для покращення нинішнього становища в даному напрямі, зокрема, ие створення Урядом Комісіӥ з питань виконання рішень Європейського суду з прав людини.

Авторами надаються пропозииї щодо вирішення иієї проблеми. Зокрема, як шлях до вирішення розглядається необхідність внесення змін до відповідного законодавства та збільшення видатків з Державного бюджету на виконання рішень Європейського суду з прав людини, оскільки, за статистикою, на першому місці - невиконання рішення в частині виплати відшкодування.

Ключові слова: рішення ЄСПЛ, Європейський суд з прав людини, виконання рішень ЄСПЛ, Комітет Міністрів Ради Європи, Конвенція про захист прав людини і основоположних свобод.

Постановка проблеми. Одним із критеріїв визначення ступеня демократичного розвитку сучасної держави є рівень гарантування нею прав та свобод людини, а ще найголовнішим - ступінь реалізації державою таких прав.

Кожна особа наділена правом на судовий захист, у процесі реалізації якого може використати всі національні засоби захисту $\mathrm{i}$, не отримавши за допомогою останніх дійсного захисту власних прав, має можливість звернутися до Європейського суду з прав людини (далі - ЄСПЛ) як до остаточного можливого варіанту задоволення власних вимог. Рішення ЄСПЛ є обов'язковим 3 тієї підстави, що Україна, приєднавшись до Конвенції про захист прав людини і основоположних свобод (далі - ЄКПЛ), визнала юрисдикцію ЄСПЛ та взяла на себе зобов'язання щодо обов'язкового виконання його рішень.

Однак натепер можемо спостерігати негативну тенденцію щодо низького рівня виконання таких рішень. Затримуючи або умисно не виконуючи рішення ССПЛ, держава демонструє низьку правову культуру 
та міжнародно-правову безвідповідальність. Щоб запобігти цьому, актуальним є розгляд процедури виконання рішення ССПЛ та чинників, які виступають перешкодою для цього.

Аналіз останніх досліджень та публікацій. Проблема виконання рішень ЄСПЛ в Україні була предметом дослідження таких науковців: В. В. Кострицького, Д. М. Супрун, Н. В. Камінської, М. Чугуєвської, І. І. Лукашука, Н. Коломієць, Е. Л. Трегубова та інших. Їхні роботи дали можливість дізнатися більше про аспекти виконання рішень ЄСПЛ Україною.

Мета статті - загальний розгляд механізму виконання рішень ССПЛ в Україні, визначення системних недоліків у національній правовій системі, що перешкоджають належному виконанню таких рішень, надання пропозицій щодо вирішення окресленої проблеми.

Виклад основного матеріалу. Виходячи зі змісту ч. 4 ст. 55 Основного закону України, особа має право звернутися за відновленням порушених прав і свобод до відповідних міжнародних судових установ чи до відповідних органів міжнародних організацій, членом або учасником яких є Україна [1]. Підставою для звернення є вичерпання всіх засобів захисту державного рівня. Норма, яка регулює використання всіх національних засобів захисту, визначена також і статтею 35 Протоколу № 11 до Конвенції. Зазначена вимога виступає одним із критеріїв прийняття заяви.

Україна, ратифікувавши 17 липня 1997 року Європейську конвенцію про захист прав людини та основоположних свобод 1950 року, взяла на себе зобов'язання щодо гарантування закріплених у ній та в протоколах до неї прав, а також визнала юрисдикцію Свропейського суду 3 прав людини, який є контрольним механізмом даного міжнародного акта. Преюдиційність рішень даного органу зумовлена його роллю та значенням для реального дотримання закріплених Конвенцією основоположних прав людини - він становить собою єдиний орган тлумачення «живого інструменту», яким є СКПЛ. Останнє відбувається динамічно, виходячи 3 умов сьогодення. Підтвердженням авторитетного статусу рішень ЄСПЛ виступає також Закон України «Про виконання рішень та застосування практики Європейського суду з прав людини» (далі Закон), котрий містить положення про те, що суди застосовують під час розгляду справ Конвенцію та практику Суду як джерело права, це зазначено у ст. 17. Також правовою основою для втілення рішень ССПЛ на національному рівні є ст. 46 Конвенції про захист прав людини і основоположних свобод, у якій зазначено, що високі Договірні Сторони зобов'язуються приводити в дію остаточні рішення Суду в будь-яких справах, у яких вони є сторонами [2].

Етапи виконання рішень ЄСПЛ в Україні регламентовані вищезазначеним нормативно-правовим актом, а до такої процедури залучені: Орган представництва, відповідальний за координацію виконання рішень ЄСПЛ, яким є Міністерство юстиції України в особі Урядового уповноваженого у справах Європейського суду з прав людини, діяльність якого забезпечується Секретаріатом; Кабінет Міністрів України.

Відповідно до ст. 5 Закону, протягом десяти днів від дня одержання повідомлення про набуття Рішенням статусу остаточного Орган представництва надсилає стислий виклад Рішення Стягувачеві (особі, за заявою якої ЄСПЛ постановлено рішення / iï представнику / правонаступнику / особі (групі осіб), на користь якої рішенням Свропейського суду з прав людини визначено обов’язок України в міждержавній справі) Уповноваженому Верховної Ради України 3 прав людини, всім державним органам, посадовим особам та іншим суб'єктам, безпосередньо причетним до справи, за якою постановлено Рішення [3].

Своєю чергою Секретаріат протягом десяти днів від отримання повідомлення Суду про те, що Рішення є остаточним, надсилає стягувачеві повідомлення з роз'ясненнями його прав щодо виконання рішення, оригінальний текст та переклад рішення до Державної виконавчої служби.

Державна виконавча служба впродовж десяти днів з дня отримання документів розпочинає виконавче провадження. Зі спливом одного місяця від дня відкриття виконавчого провадження за Рішенням Секретаріат надсилає до Державної казначейської служби постанову про відкриття виконавчого провадження разом із автентичним текстом і перекладом Рішення. Стадія саме виконання рішення ЄСПЛ настає після оприлюднення офіційного перекладу тексту (публікації в газетах «Урядовий кур'єр» і «Голос України»). Джерело розміщує стислий виклад Рішення протягом семи днів від дня його отримання.

Протягом десяти днів від дня отримання зазначених документів Державна казначейська служба здійснює списання на вказаний стягувачем банківський рахунок, а якщо він відсутній - на депозитний рахунок ДВС.

Розрахунок за відшкодуванням має бути здійснений протягом трьох місяців з моменту набуття Рішенням статусу остаточного або 
у строк, який зазначається у рішенні. У разі порушення строку на суму відшкодування нараховується пеня.

Міжнародний контроль за таким виконанням покладається на Парламентську асамблею Ради Європи (далі - ПАРЄ) та Комітет Міністрів Ради Свропи (далі КМРС), які мають право видавати Резолюції з вимогами вжити дієвих заходів до Урядів держав, які затримують виконання рішень або не виконують їх зовсім. Серед таких заходів можуть застосовуватися санкції у вигляді виключення з Ради Свропи.

Так, наприклад, 30 вересня 2015 року депутатами ПАРЕ було ухвалено резолюцію «Виконання рішень Свропейського суду з прав людини». Основу резолюції становила доповідь щодо наявності структурних проблем в юридичних системах певних країн, які стають передумовами для великої кількості подібних позовів. Серед таких країн Україна, Польща, Росія, Туреччина, Румунія та інші. Також у документі містилася теза щодо відсутності в Україні прогресу з виконанням вироків ЄСПЛ. Окрім того, за даними КМРЕ, було зазначено, що на виконання рішення ЄСПЛ громадянам України доводиться чекати в середньому 7,4 років [4].

3 ратифікацією Україною Протоколу № 14 до Конвенції суттєво зросла роль КМРЄ у механізмі контролю за виконанням рішень у нашій державі, оскільки 3 цього моменту даний орган отримав можливість бути ініціатором перед ЄСПЛ щодо питання про недодержання державою - учасницею Конвенції - власних зобов'язань, пов'язаних з виконанням остаточних рішень Суду. У разі виявлення Судом порушення ч. 1 ст. $46 \mathrm{Koн}-$ венції Комітет Міністрів вживає зазначених заходів щодо цієї держави [5].

Відповідно до статистики, наданої Міністерством юстиції України, впродовж 20152019 років було визнано КМРС такими, що виконано - 14, 4, 100, 318, 443 рішення відповідно. На введення в дію рішень ЄСПЛ з державного бюджету було сплачено:

- у 2015 році - 639981 892, 09 грн.;

- у 2016 році - 612294315,54 грн.;

- у 2017 році - 61 365,79 тис. грн.;

- у 2018 році - 32646827,39 грн. [6]

Виходячи $з$ опублікованої Офісом Ради Європи статистики, Україна займає сьоме місце $з$ кінця в рейтингу держав, що не виконують рішення ЄСПЛ. Станом на 6 липня 2019 року нашою державою було виконано рішень у 63,48 \% випадків (944 справи) [7]. Перш за все це демонструє ставлення до громадян України, які зневірилися у судовій владі держави і шукають справедливості у міжнародних органах.
Розглянемо цю проблему у фінансовому аспекті. Варто зазначити, що ССПЛ здебільшого призначає грошову компенсацію заявнику, i, підсумовуючи кількість звернень, можна спрогнозувати значну суму коштів, до якої бюджет держави може виявитися не готовий. Через те, що державний бюджет формується щорічно, заздалегідь забезпечити належну грошову масу на практиці не $€$ можливим. Таким чином, нинішня бюджетна політика не відповідає політиці Свропейського Союзу і позбавляє громадян України можливості відновити порушені права. Виходячи з цього рішенням даного питання буде пошук новим методик планування державного бюджету.

Як відомо, 1 квітня 2020 року було створено Комісію з питань виконання рішень Європейського суду з прав людини. Рішення було прийняте на засіданні Кабінету Міністрів. Цей крок дозволить забезпечити ефективну взаємодію органів державної влади для своєчасного виконання рішень ЄСПЛ. Гостро стояло питання забезпечення чіткої взаємодії усіх гілок влади - як законодавчої, так і виконавчої та судової. Адже належне виконання Україною своїх міжнародних зобов'язань позитивно вплине на імідж держави [8]. Створення Комісії матиме позитивний результат за умови, якщо у виконанні рішень ЄСПЛ будуть враховуватися не тільки фінансовий аспект виконання рішень, а ще й відновлення порушених прав і запобігання новим порушенням. Необхідність саме таких заходів обгрунтована тим, що рішення ЄСПЛ повинні стати взірцем та орієнтиром у судочинстві нашої держави. Базуючись на практиці міжнародних органів, громадянам України необхідно забезпечити належний захист на національному рівні.

\section{Висновки}

Отже, натепер наявна неузгодженість нормативно-правових актів, яка негативно впливає на судочинство та виконання рішень ЄСПЛ. Тримаючи вектор до Європейського Союзу, Україна має більш відповідально ставитися до питання виконання рішень міжнародних організацій та брати за основу судочинство ЄСПЛ.

Зокрема, потребують удосконалення положення Закону України «Про виконання рішень та застосування практики Європейського суду з прав людини» в частині виплати стягувачеві відшкодування, які натепер не приведені у відповідність до європейських вимог, а тому позбавляють громадян України права на своєчасне та в повному обсязі отримання відшкодування, присудженого Європейським судом з прав людини. 
Для розрахування та закладення в Державний бюджет відповідних асигнувань, спрямованих на виконання рішень ЄСПЛ, необхідним є формування в нашій державі відповідного реєстру, в якому будуть міститися підтверджені відомості щодо необхідних для забезпечення виконання судових рішень коштів.

\section{Список використаних джерел:}

1. Конституція України від 28 червня 1996 p. URL: https://zakon.rada.gov.ua/laws/ show $/ 254 \% \mathrm{D} 0 \% \mathrm{BA} / 96-\% \mathrm{D} 0 \% \mathrm{~B} 2 \% \mathrm{D} 1 \% 0$ (дата звернення: 20.03.2020).

2. Конвенція про захист прав людини i основоположних свобод. Редакція від 02 жовтня 2013 p. URL: https://zakon.rada.gov.ua/laws/ show/995_004 (дата звернення: 20.03.2020).

3. Про виконання рішень та застосування практики Європейського суду 3 прав людини: Закон України від 23 лютого 2006 р. № 3477-IV. URL: https://zakon.rada.gov.ua/laws/ show/3477-15 (дата звернення: 20.03.2020).
4. Власенко В. Резолюція ПАРС: За невиконання рішень Європейського суду можуть виключити з Ради Європи. URL: https://p.dw.com/ p/1GgE3 (дата звернення: 22.03.2020).

5. Протокол № 14 до Конвенції про захист прав людини і основоположних свобод, який змінює контрольну систему Конвенції від 13 травня 2004 p. URL : http://zakon4. rada.gov.ua/laws/ show/994 527 (дата звернення: 22.03.2020).

6. Оффіційний веб - сайт Міністерства юстиції України. URL: https://minjust.gov.ua/ $\mathrm{m} /$ informatsiya-schodo-vikonannya-rishenevropeyskogo-sudu-z-prav-lyudini-u-spravah-protiukraini (дата звернення: 23.03.2020)

7. Попов С. Україна посідає 7-е місце 3 кінця з невиконання рішень Європейського суду 3 прав людини. URL: https://sud.ua/ru/news/ publication/150919-ukrayina-zaymaye-7-mistse-zkintsya-po-nevikonannyu-rishen-yevropeyskogosudu-z-prav-lyudini (дата звернення: 23.03.2020).

8. Урядовий портал. URL: https:// www.kmu.gov.ua/news/uryad-stvoriv-specialnu-komisiyu-dlya-nalezhnogo-vikonannya-rishen-yespl (дата звернення: 23.03.2020).

The article is devoted to investigating the enforcement of judgments of the European Court of Human Rights, which is the control mechanism of the Convention for the Protection of Human Rights and Fundamental Freedoms and whose primary purpose is to monitor the observance of the rights enshrined in the Convention. The binding nature of such decisions is noted because, under current law, national courts apply the ECtHR Convention and case-law as a source of law when considering cases.

The article examines the possible ways in which the state executes the decisions of the European Court of Human Rights, different approaches of scientists in this regard, and defines the specificity of enforcement proceedings, which is conditioned by the special status of the body that makes such decisions. The role of the Parliamentary Assembly of the Council of Europe and the Committee of Ministers of the Council of Europe in determining the implementation of judgments of the European Court of Human Rights is determined.

Attention is drawn to the existing problem of not very high figures and the length of time the judgments of the European Court of Human Rights have been enforced, as a result of which Ukraine has found a violation of the Convention, analyzing the factors that led to such a situation. Statistics of the level of implementation of decisions for 2015-2019 are provided. The responsibility of the state to the person, for whom the decision was made, is considered for its late implementation. Systemic issues are highlighted, the existence of which, in Ukraine, is an obstacle to the proper implementation of the decisions of the European Court of Human Rights.

It is emphasized that enforcement of judgments proves that in our country there are indeed guarantees of human right to a fair trial, but the low level of such en forcement makes such guarantees to be declaratory. The article lists the measures that our country is taking to improve the current situation in this area, in particular the creation by the Government of the Commission on the enforcement of judgments of the European Court of Human Rights.

The authors provide suggestions for resolving an existing problem. In particular, the way to a solution is to consider the need to amend the relevant legislation and increase the expenditures from the State budget for the implementation of judgments of the European Court of Human Rights, since, according to statistics, in the first place - non-enforcement of the decision regarding payment of compensation.

Key words: ECtHR decision, European Court of Human Rights, enforcement of ECtHR decisions, Committee of Ministers of the Council of Europe, Convention for the Protection of Human Rights and Fundamental Freedoms. 